\title{
Mirror-mirror on the Wall, What Psychological Effects of COVID-19 and Strategies Practiced can Prevent Deterioration of Mental Health by Malaysian of All?
}

Choe Chai Tan, Noor Syamilah Zakaria, Yusni Mohamad Yusop, Nur Aira Abdrahim

To Link this Article: http://dx.doi.org/10.6007/IJARBSS/v11-i8/10696 DOI:10.6007/IJARBSS/v11-i8/10696

Received: 25 June 2021, Revised: 30 July 2021, Accepted: 20 August 2021

Published Online: 29 August 2021

In-Text Citation: (Tan et al., 2021)

To Cite this Article: Tan, C. C., Zakaria, N. S., Yusop, Y. M., \& Abdrahim, N. A. (2021). Mirror-mirror on the Wall, What Psychological Effects of COVID-19 and Strategies Practiced can Prevent Deterioration of Mental Health by Malaysian of All? International Journal of Academic Research in Business and Social Sciences, 11(8), 1748-1766.

\section{Copyright: (c) 2021 The Author(s)}

Published by Human Resource Management Academic Research Society (www.hrmars.com)

This article is published under the Creative Commons Attribution (CC BY 4.0) license. Anyone may reproduce, distribute, translate and create derivative works of this article (for both commercial and non-commercial purposes), subject to full attribution to the original publication and authors. The full terms of this license may be seen

at: http://creativecommons.org/licences/by/4.0/legalcode

Vol. 11, No. 8, 2021, Pg. 1748 - 1766

Full Terms \& Conditions of access and use can be found at http://hrmars.com/index.php/pages/detail/publication-ethics 


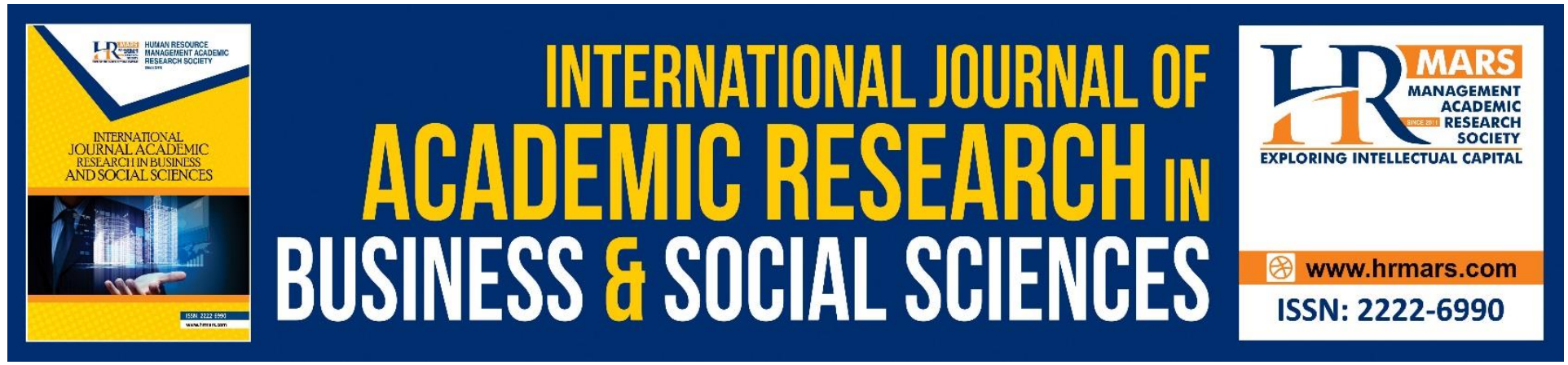

\title{
Mirror-mirror on the Wall, What Psychological Effects of COVID-19 and Strategies Practiced can Prevent Deterioration of Mental Health by Malaysian of All?
}

\author{
Choe Chai Tan ${ }^{1,2}$, Noor Syamilah Zakaria ${ }^{1}$, Yusni Mohamad \\ Yusop ${ }^{1}$, Nur Aira Abdrahim ${ }^{1}$ \\ ${ }^{1}$ Faculty of Educational Studies, Universiti Putra Malaysia, Malaysia \\ ${ }^{2}$ General Studies Department, Sunway College, Malaysia \\ Email: celinet@sunway.edu.my
}

\begin{abstract}
On a daily basis, the number of global COVID-19 cases is increasing rapidly. In Malaysia, the number of confirmed cases surged after the September 2020 Sabah state election. This caused the government and the Ministry of Health to issue warnings and to once again impose restrictions of movement. Many Malaysians who had gone through the strict Movement Control Orders (MCOs) imposed since March 2020 had to face the psychological effects of the consequent economic recession once again and adapt to their new daily routines under the MCOs. With new increases in the numbers of confirmed cases, the level of anxiety has risen sharply, especially the uncertainty of when the threat of COVID-19 will be lessened. It is pertinent to explore both the psychological and emotional impact to find ways to reduce the stress and effectively address the mental health issues arising from this pandemic. This paper focuses on the causes of uncertainties faced by Malaysians and the strategies employed to overcome these effects. Essentially, there are internal and external methods which can be a guide to individuals to help them develop better coping skills in this anxious situation. Individuals should be aware of their emotional state and practise self-care to prevent a decline of their mental health.
\end{abstract}

Keywords: COVID-19 Pandemic, Psychological Effects, Stress, Anxiety, Self-Care.

\section{Introduction}

The unexpected outbreak of COVID-19 all over the world has caused significant uncertainty, fear and stress in many people. When Malaysia locked down on 18 March 2020, it was successful in keeping the numbers low by strictly imposing the Movement Control Order (MCO) although it had experienced two waves of the disease. Unfortunately, Malaysia entered the third wave of the pandemic due to the Sabah state election in September 2020. Since then, the number of Covid-19 cases has tripled compared to the earlier first two waves. According to Malaysia Ministry of Health (MOH) report, the total number of confirmed COVID- 
19 cases on 25 July, 2021 was 1,013,438 with 7,994 deaths (Ministry of Health, 2020b). Compared to one year ago, this figure was 8,884 confirmed cases with 123 deaths reported (Ministry of Health, 2020a). This is an increase of $11,407 \%$ in confirmed cases and $6,499 \%$ increase in deaths (Table 1). It has caused great anxiety and fear among many Malaysians. At the time of writing, the number of confirmed cases is still increasing daily even though the government has imposed several MCOs nation-wide.

\section{Table 1: Comparison of July 2020 and July 2021 Confirmed COVID-19 Cases in Malaysia}

ver the past decades, there have been several world health crises in several countries such as the severe acute respiratory syndrome (SARS) coronavirus, the highly pathogenic avian influenza (HPAI) H5N1 virus, Avian Flu, Zika Virus and Ebola (Bryce et al., 2020). However, Malaysia was not badly affected by these diseases which were quickly brought under control. The most serious epidemic in Malaysia was the outbreak of the Nipah encephalitis virus in 1998, which resulted in 109 deaths (Tee et al., 2009) but the epicentre was a small, isolated area. As a result, most Malaysians were not affected.

When the COVID-19 epidemic in China was first brought to the world's attention by the World Health Organisation (WHO) in their report on 31 January 2020 (World Health Organization, 2020a), many countries did not take it seriously. At that time, some suggested that we should not be overly worried about the spread of the disease but should avoid the trap of "probability neglect" that would cause panic (Sunstein, 2020). Many were influenced by these suggestions because past experiences have shown that epidemics were quickly brought under control and did not spread widely. When the government of China imposed a lockdown in Wuhan on 23 January 2020, other countries sympathized with the Wuhan residents and hoped that the affected would recover quickly. Many Malaysians did not realize how deadly this new virus was as their attention was diverted by the internal political crisis that time (Shah et al., 2020). They did not foresee that there would be a major pandemic which would result in the loss of lives, a stumble in financial stability, emotional and psychological stress for all. This was despite the warning from the United Nations (UN) health professionals to world leaders of a potential global mental health catastrophe as a result of millions facing diseases and deaths, financial stress and anxiety as well as being restricted in movement control orders due to the current pandemic (Kelland, 2020).

Many world leaders and the general population had not expected the pandemic to spread so rapidly in such a short period and affect almost everyone all over the world. What was normal before COVID-19 is no longer the norm in this pandemic. It has brought challenges to all regardless of age, race, gender, status, or nationality. Since 18 March 2020, Malaysians have been under an MCO which has been continually extended each fortnight owing to the rise in confirmed cases of COVID-19.

\section{Movement Control Order (MCO)}

Movement Control Order (MCO) or lockdowns has become an almost standard protocol to control the spread of COVID-19 globally. In China, Wuhan was the first city which had a lock down and it was an unprecedented and remarkable decision although it was beyond WHO guidelines (Reuters, 2020). WHO acknowledges that some countries had to implement stayat-home orders to reduce the chances of COVID-19 transmission. However, WHO also reminded that such measures could have a serious negative impact on individuals, communities, and on the social and economic aspects of society (World Health Organization, 
2020b). Malaysia implemented MCOs when COVID-19 confirmed cases started escalating from 18 March 2020 onwards. Table 2 below explains the phases of MCOs in Malaysia:

\section{Table 2: The Phases of MCOs in Malaysia}

Malaysia experienced a third wave in September 2020, and it was tougher to curb compared with the previous two waves. Malaysia Prime Minister admitted that the cause of the third wave of COVID-19 was due to the Sabah state election (Rampal \& Liew, 2021).

In the first phase of the MCOs, the movements of people were severely restricted. The people were updated on the latest news and regulations on government websites and phone apps. Some studies have revealed that the pandemic had negative psychological effects on those who had to undergo quarantine. These effects include confusion, stress, depression, grief, fear, insomnia, anger, impatience, anxiety and post-traumatic stress symptoms (Banerjee, 2020; Pfefferbaum \& North, 2020). Among the stressors were the lack of information, long quarantine periods, fear of infection, inadequate food supplies, boredom and financial loss. Some researchers found that respondents who had undergone quarantine during past pandemics have continued to show symptoms of depression three years after. This shows that for some, there were long-term effects (Brooks et al., 2020). This finding was supported by a health psychology professor, that there was a price to pay for the implementation of a quarantine or a lockdown (Hoof, 2020). In Malaysia, the Health-Ministry revealed that its mental health hotline had received 9,338 calls as of 3 June 2020 and this number is increasing daily. The majority of the callers requested emotional support because of loss of jobs and income, loss of hope, stress and interpersonal issues during the pandemic (Tang, 2020). The condition became worse in year 2021, as between March 25, 2020 to May 20, 2021, there are 145,173 calls received by government mental-health hotlines ("Analysis: Mental Health Issues" 2021). If emotional support were not provided on time, it may lead to other mental issues such as depression, various types of abuses (domestic, drugs) and even suicide.

During an MCO, there is limited physical social interaction with others, even when carrying out essential activities. Virtual interactions such as online meetings, online classes and other online communication cannot replace the face-to-face interaction in daily life. A research study has indicated that online interpersonal communication cannot improve the quality of life compared with face-to-face interaction in daily life. It was due to lack of "warmth", social and personal interactions, and engagement in virtual communication (Lee et al., 2011).

Past research on the severe acute respiratory syndrome (SARS) epidemic found that the risk of post-traumatic stress disorder (PTSD) was high and this is to be expected to be the same post- COVID-19 (Sekowski et al., 2021). This is confirmed by psychiatrists from Oxford University that almost one in five coronavirus patients developed some mental illness within three months of being diagnosed with Covid-19 (Schladebeck, 2020). Hence, proactive action should be taken by every individual, healthcare personnel should be warned of the risks of PTSD of COVID-19 survivors and be ready for the necessary therapeutic interventions (Sekowski et al., 2021).

\section{Psychological Uncertainty \\ New Routines \\ Work from Home (WFH)}

The most drastic change brought about by the MCOs in Malaysia was the immediate transition from working from the office to working from home. This required a shift from traditional working methods to digital platforms starting from 18 March 2020. Office 
meetings were moved from physical meeting rooms to laptops and virtual platforms like Zoom, and Microsoft Teams. In addition, people were encouraged to do their shopping online. Undoubtedly, this has greatly affected many workers who are not able to work from home and also not in the essential's services such as sales and service workers, construction workers, administration workers, installation and maintenance workers, transportation workers, agriculture workers and leisure and hospitality workers.

Department of Statistics Malaysia (2020) reported that $46.6 \%$ of self-employed employees had lost their job, whereas $94.8 \%$ of self-employed workers experienced reduction in their monthly income. Not all sectors are able to work from home as statistics reported the percentage of people working from home for each sector are - self-employed $(25.1 \%)$, employer (30.9\%), government link company $(73.7 \%)$, private employee $(48.95 \%)$ and Multinational company employee $(80.8 \%)$. From the statistics, three in four self-employed people and half of the private employees surveyed were unable to work from home. With more severe COVID-19 cases and pro-long MCOs in 2021, the negative effect on the Malaysian's income will be greater than 2020.

\section{Online Teaching and Learning}

Primary, secondary, and tertiary students had to use online learning platforms during the MCO period so that their studies were not disrupted. Teachers and students had to cope with unstable Internet access and other challenges of online teaching and learning platforms such as messaging services and online teaching apps. However, they were hampered by other problems like the access to the Internet and hardware issues. A study conducted in Malaysia showed that only $6 \%$ of the students have access to a personal computer, $5.76 \%$ to a tablet, $9 \%$ to a laptop and $46 \%$ to a smartphone (Yeoh, 2020). Many parents are concerned that there is a deferment of face-to-face classes and have doubts on the effectiveness of online learning. On the other hand, students taking public examinations are relieved that they would have more time to prepare for their exam (Lee, 2020).

Although each mobile phone subscriber is given $1 \mathrm{~GB}$ free data during the $\mathrm{MCO}$, this is still not sufficient for online learning. In addition, unstable internet connections, and slow speed mean that students face a lengthy time downloading or uploading learning materials. These challenges affect the students' capability to adapt to e-learning (Yeoh, 2020). Another drawback of online learning is the digital divide between poor students who lack the hardware to participate in online classes or those who live in rural areas where there is limited internet access, and students who can afford the gadgets or have greater internet access (Bernama, 2020a).

\section{Online Teaching-learning Activities and Challenges}

Having the right tools such as laptops/computers at home and Wi-Fi stability, speed and security are the main factors for a successful WFH/LFH (Learning From Home). During the $\mathrm{MCO}$, there was an increase in Internet usage. Consequently, the network infrastructure was unable to cope with the demand, resulting in frequent disconnection, intermittent service, and slow loading. Additionally, self-discipline, self-motivation and distractions at home can affect the activities of WFH/LFH (Goh, 2020). This can be challenging for rural and suburban residents. It was reported that a university student had to climb a tree to obtain better Internet access because of limited broadband services (Lee, 2020). This clearly shows that the rural areas in Malaysia are in dire need of better and advanced connectivity. While the new 
platform for learning has created opportunities for exploring digital learning skills, it has also manifested the technological divide between the rural and urban population.

Besides unreliable network and technical issues such as unstable connection of the Internet, other common issues include old computers, absence of webcams, refusal to switch on webcams or computers freezing up during online classes are common (Noh \& Nawa, 2020). Another finding indicates that almost one-third of the university students in Malaysia also experienced anxiety during the Covid-19 pandemic (Sundarasen et al., 2020).

Not only did the MCO affect students but it also severely impaired private colleges and universities which do not receive financial support from the government. According to the Malaysian Association of Private Colleges and Universities, new foreign students are not allowed to enter the country during the MCO. As such, many did not enrol with the local private universities as they preferred physical classes to online classes. With low enrolments, at least $20 \%$ of the 440 private higher education institutions in Malaysia were at risk of closure. A higher education management specialist, Dr. Geoffrey Williams, has estimated that $97 \%$ of universities and university colleges will make losses and $51 \%$ would become insolvent (Babulal \& Solhi, 2020).

\section{On and Off MCOs and Inconsistent SOPs}

During the first two phases of the MCO, strict Standard Operating Procedures (SOPs) were imposed by the government, and all had to be adhered to. The people were allowed to go out only when necessary and had to ensure they were sufficiently protected to prevent the spread of infection. Everyone was required to wear a face mask, use hand sanitiser and wash hands regularly and thoroughly. Social distancing of at least one meter was a standard requirement. So, if someone comes too near, it can be psychologically stressful, especially for those who are susceptible to anxiety attacks.

With the many stages of MCOs and new SOPs, the public are confused with the on-off MCOs and double standards in enforcing these SOPs. Many Malaysians express their dissatisfaction on social media on the new rule allowing Cabinet ministers returning from official overseas visits to self-quarantine for a three-day observation whereas the public need to go through a ten-day mandatory quarantine (Gangadaran, 2021). The new rule with insufficient scientific and rationale support could worsen the public's trust in the government's determination to curb the outbreak and the fairness in execution of SOPs.

In addition, from 11 March 2021 onwards, individuals who violate the SOPs can be fined up to RM10,000. For the companies and corporation that flout the SOPs can be fined up to RM50,000 (Bernama, 2021). On 31 May, 2021, 630 individuals were issued with compound notices and 45 were remanded due to MCO violation (Anis, 2021). Such a huge increase in penalty is to stem out SOP violation, but it can be a stressor to the general public who are already overwhelmed by financial and emotional stress. Another alternative to educate the public for not adhering to the SOPs is for them to do compulsory community service at the Quarantine or Vaccination Center. This could be more effective than imposing stiff penalties.

\section{Political Impasse}

The 7th Prime Minister of Malaysia, Tun Dr. Mahathir Mohammad unexpectedly resigned at the end of February 2020. Malaysians have to deal with not only the COVID-19 outbreak but 
also a political crisis in the country. Subsequently, a new prime minister, Tan Sri Muhyiddin Yassin was sworn in on 1 March 2020. This crisis arose because the new government had not been democratically elected. With the mounting challenges of the COVID-19, political and the resultant economic crises, Malaysians face more stressors than others.

The Malaysian King approved the government's request to declare an emergency order on 12 January 2021 up to 1 Aug 2021 with the intention of curbing COVID-19 cases (Teoh, 2021). His Majesty wants all Malaysians to put aside their political, racial and religious differences, and unite in fight against the COVID-19 pandemic. Unfortunately, the emergency order was not successful in reducing the number of COVID-19 cases. They continue to soar from Jan 12, 2021 $(3,309$ cases) to the day of writing today, July 25,2021 (17,045 cases). This shows an increase of 515\% (Table 3). The maximum new cases continue to rise on the daily basis and now it has reached more than one million (Ministry of Health, 2021b). The figure below shows that the emergency order has failed to curb the rising numbers of COVID-19 cases.

\section{Table 3: Confirmed Cases from the Day of Emergency Order}

Clearly, the FMCO is not the solution, there are other factors which cause the rising of COVID19 cases that need to be addressed urgently by the government. Besides, the FMCO which was implemented since 1 June 2021 did not achieve the effectiveness like the MCO 1.0 which was effective in controlling the daily confirmed cases from 117 on 18 March 2020 to 47 on 18 May 2020, it was reduced by $40 \%$ in two months' time (Ministry of Health, 2020b; Ministry of Health, 2020c).

\section{Negative News and Fake News}

With the reading or hearing of the severity of confirmed daily COVID-19 cases, the public is uncertain about when the current lockdown will end, and the financial concerns are common stressors experienced by most Malaysians. Added on are some reported cases on the "empty syringe" incidents and Hartal Doktor Kontrak (HDK) movement causing uncertainty in people about the ability of the government in handling the crisis of this pandemic. The government contract doctors carried out a mass walkout on 26 July 2021 in a nationwide strike to demand for fair employment terms and improvement of job security.

To prevent the "empty syringe" incident from happening, the National COVID-19 Immunisation Programme Coordinating Minister is quick to respond. He allowed the recipients to video record their vaccination process which will ensure this process was properly done with the integrity of the front-liners of the national immunization program (Bloomberg, 2021). If any individual had been proven to receive an "empty syringe" vaccine, he will be given a new dose, as promised by the Health Ministry ("Health Minister", 2021).

As of the time of writing, Malaysia is under increasing pressure due to the continued surge of COVID-19 cases. The overworked contract doctors protested at the time when the health system was about to collapse. They want their plight to be heard by the government and a satisfactory solution to be provided (Solhi \& Krishnan, 2021). If the contract doctors' grievances are not resolved, it will be a time bomb not only for the government and health system but also the majority of Malaysians.

The media plays a very important role in the dissemination of information during a crisis. As with people all over the world, Malaysians are battling with the invisible virus but are also 
dealing with political uncertainty and economic instability. In these uncertain times, it is imperative that the media should be responsible when disseminating news without creating uncertainty, anxiety and restlessness. In this pandemic, fake news and disinformation have become an unprecedented challenge as information is forwarded and shared without discernment (Bernama, 2020b). As a result, during this pandemic, 24 people had been charged for disseminating fake news on the disease, with 152 cases under investigation (Karim, 2020).

To stricter control the spread of fake news, a new Emergency (Essential Powers) (No.2) Ordinance 2021 beginning on 12 March 2021 that imposes a fine not exceeding RM100,000 or imprisonment for not exceeding three years or both, if found guilty (Gangadaran, 2021).

\section{Consequences of COVID-19 on the Malaysian Economy}

The implementation of the MCO in Malaysia has caused impairment to almost all the economic sectors. The aftermath was the shutdown of businesses, unemployment, or even bankruptcy (Shah et al., 2020). Soaring unemployment might be worse than that during the Great Depression of 1929 or the world financial crisis of 2007. This crisis has a spiral effect as it is expected that unemployment would lead to less spending, affecting business which would force more shops to close down and more employees losing their jobs and livelihood (McGaughey, 2020).

Malaysia's Micro, Small and Medium Enterprises (MSME) sectors suffered a total of RM40.7 billion losses in 2020 and a decline of 7\% GDP contribution when compared with year 2019 (The Malaysian Reserve, 2021). FMCO is making the situation worse. If the government still cannot find a balanced solution for people's lives and livelihood, it could have a devastating impact on Malaysian socio-economic.

Rising COVID-19 cases in 2021 have sparked unemployment among Malaysia's youths, graduates and most vulnerable workers. They are paying the price of the Malaysia's on-off MCOs (Nixon, 2021). A survey indicated that Malaysian companies are more vulnerable than their counterparts in the region even before the pandemic (The World Bank, 2021). The current uncontrolled outbreak has made the situation grave.

With more than a year of on-off MCOs, many low-income families had no income and faced a lack of basic needs such as food, and other essential items for daily living. There is news that families with depleted savings are surviving on one meal per day (BBC, 2021) and a man was seen searching through a rubbish bin to look for food after midnight ("Man Scavenges for", 2021). The people and NGOs have started to help one another by setting up "food banks" and the \#bendera putih (\#white flag) movement to distribute the food to the needy.

The economic crisis is therefore affecting the mental health of the people. According to Malaysia police's data, there are 468 completed suicide cases over the first five months of 2021, compared to a total of 631 in year 2020 and a total of 609 in 2019 (BBC, 2021). The poor, the young and the females have a higher risk of mental health symptoms in this pandemic (Wong et al, 2021). Therefore, there is an urgent call to provide prevention strategies to counter mental health issues at this alarming stage. 


\section{Changing Mindset and Practicing Self-care}

With the awareness that the pandemic can generate stress-inducing demands, it is worthwhile developing self-care skills to cope with these stress-activated demands (Lyon, 2002). A person can change his own mindset to adapt to the psychological uncertainty in his life and to prevent the deterioration of mental health at this difficult time. There are internal and external self-care methods (Figure 1) which can contribute to enhance our well-being during this pandemic.

\section{Figure 1: Internal and External Self-Care Internal Methods}

Internal self-care methods in this study are focused on individual cognitive thinking and reconnecting to oneself. In the internal self-care, the individual is allowed to control their own feelings without getting external assistance.

\section{Accept New Routines, and Discard Unrealistic Expectations}

It is a fact that life in the near future or even in the long term will not return to what it was before. It is possible that the general public may have to adapt to a new norm which requires the wearing of a face mask in public places, the use of hand sanitizers, and frequent washing of hands. The MCOs also forced many to stay at home and to WFH/LFH. However, there is more time for family activities, home study and work. In this aspect, one has to realise the importance of time management. It is foolhardy to think that one can work 24 hours to become the ideal parent, student, or employee. To reduce stress and anxiety, it is important to have a "To do list" daily. For example, when WFH, a worker can reduce stress by ordering food online if one has too much work. To prepare for working on virtual platforms, one should take the initiative to attend online training courses or get help from colleagues. Proper planning and setting realistic targets are important to maintain control of one's life and reduce stress in difficult times. Besides that, it is important to accept the new norm and appreciate one's physical and mental health, and not to be distracted or stressed out by the social media but to remember to keep one's perspective and live within one's means.

\section{Accept New Regulations and Adapt Quickly}

Under the MCO, there were many new regulations and SOPs that caused uncertainty and confusion of the consequences by violating the regulations. Many people who were not aware of the regulations were fined RM1,000 for violating the MCO (Chan, 2020). The latest regulation on 12 March 2021, increased the penalty up to RM10,000 if flouting the SOPs. For one to cope during the pandemic, it is necessary to understand and be updated on the new regulations and to adapt to the situation accordingly.

Flexibility is the key to facing the uncertainties of life. The individual is encouraged to accept changes willingly, adapt to the new normal and have an open mind. In the pandemic, individual has to adhere to new procedures, practise new health and social routines, take proper intervention and respond to negative emotions. Individual has to seek help or offer help-when the need arises. If everyone takes charge of his own self-care, the negative psychological effects such as stress and anxiety can be minimised.

\section{Focus on What can be Controlled, and not What Cannot be Controlled}

It is extremely challenging for any government during the COVID-19 pandemic. Many countries around the world adopted the similar measures to stop the virus from spreading 
(Bryce et al., 2020). In this troubled time, the most important issue is how to protect people from the infections and to survive. A movement \#KitaJagaKita (We take care of one another) to gather a list of non-governmental organisations (NGOs) has been established to help those who are badly affected by the MCOs (Savitha, 2020).

The Malaysian government announced the National Recovery Plan (NRP) on 15 June 2021 to set the three threshold indicators on how the country can transit from phase one to four for an exit strategy. These three indicators include daily cases of COVID-19, public healthcare capacity is at a safe level based on the rate of ICU ward occupancy, and the percentage of Malaysia's population who have completed two doses of vaccination (Bernama, 2021b).

This National Recovery Plan is a target for the government to guide Malaysians to move out of the pandemic crisis over four phases. Out of the three criteria, the third one which is to increase the percentage of Malaysia's population to be fully vaccinated is what we can control. If the majority of the population have been fully vaccinated, the COVID-19 confirmed cases will be reduced and chances of being admitted to ICU will be lower too. It is a causeand-effect cycle and it is controllable by us. If everyone does their part by getting vaccinated, we might achieve the fourth phase as indicated in the National Recovery Plan by end of 2021.

\section{Awareness of the emotional changes during social isolation}

Awareness of the present mindfulness and acceptance of the inevitable stress and changes that have become a part of daily life require the individual to practise self-care. This is psychologically beneficial and contributes to the individual's mental well-being (Coyne et al., 2020).

Studies also found that people have lower levels of anxiety and depression when they wear masks. Therefore, to reduce anxiety, sufficient supply of masks, alcohol-based hand sanitizers and other personal hygiene products during the epidemic is vital (Wang et al., 2020; Guo, 2020). Wearing a mask, maintaining social distancing and washing hands while effectively reducing the transmission of the virus, can increase the positive feeling of individuals because they feel they have taken all necessary precautions to protect themselves. If anxiety and worry still exist, it is a common psychological reaction which can be identified as COVID-19 trauma. If such emotions affect their daily lives, they should seek professional help.

It is imperative that there are new mental health programmes to cater to individuals and vulnerable groups during the pandemic. In addition, there are other more innovative solutions available: the use of technology to enhance mental health systems to support service delivery, the use of social media to promote mental health and the availability of interventions. The development of teleconsultations and electronic health records systems to facilitate distant care delivery should be supported (Maulik et al., 2020).

Sood (2020) recommends that counsellors provide on-line support as well as practical and applicable interventions for those who have mental health conditions during the MCO. Another research suggests that psychological interventions such as Cognitive Behavioural Therapy (CBT) can be conducted online and customised to the needs of the public (Wang et al., 2020). 


\section{Convert negative thoughts to a positive mindset}

Thoughts in negative situations can be controlled and managed by focusing on something positive (Lyon, 2002). To help eliminate toxic thoughts, individual can spend some time to assist someone in need. Positive activities such as feeding the hungry or collecting donations to help the needy can reduce negative thoughts and make a person happy.

\section{External Methods}

External self-care methods in this study mean seeking outside help. When individuals cannot handle problems by themselves, they should explore external sources which can improve their mental health.

\section{Find the Right Channel to Obtain News}

The Malaysian authorities are using two strategies to prevent the spread of misinformation in the country. First, the Malaysian Communications and Multimedia Commission (MCMC) launched a rapid response team to deal with dubious COVID-19 news on the social media. Fake news will be identified and labelled as such on its website sebenarnya.com. Second, Malaysians were reminded about the consequences of circulating false news. It entails a fine of up to RM100,000 or an imprisonment up to two years, or both. This is intended to dissuade the public from posting false information (Yusof, 2020).

In addition, the Health Ministry updates the public daily with the latest health information. This is important because results of studies have shown that a higher satisfaction with the health information received is linked to a lower psychological impact of the epidemic which, in turn, leads to a lower level of stress, anxiety and depression (Wang et al., 2020).

\section{Get the Right Resources and Assistance to Secure a Job or Create Own Business}

For Malaysians who have recently lost their jobs, they can utilise the available government channels for monetary aid, such as, Employment Insurance system (EIS) to provide financial assistance for employees who are losing jobs ("Lost Job Assistance", 2021)

To overcome the unemployment issue, Blustein et al (2020) suggests six phases of the research programme. The first is the review of the individual's unemployed situation. The second is the assessment of the individual's strengths. The third is the matching the skills of the unemployed with the organisations' needs. The fourth is the retraining of the unemployed. The fifth is directing the individual to a proper channel for help. The final stage is regular evaluation and adjustment.

Unemployment can be a major stressor to an individual who has dependants and financial responsibilities. The unemployed has to be proactive and utilise technology in looking for employment. The individual should explore other options such as online businesses or up-skill themselves with digital literary and e-commerce skills. With the new normal, Malaysians are more used to online purchasing and cashless payment transactions. As stated by Malaysia Finance Minister, the online sales grew by 40\% due to the pandemic ("Corona Virus", 2021).

Meanwhile, individuals could utilize the entitlement offered by the federal government for COVID-19 Financial Assistance. This Pakej Perlindungan Rakyat dan Pemulihan Ekonomi (PEMULIH) worth RM150 billion (Ministry of Finance, 2021), included cash assistance for individuals with low income, loss of income, jobseekers, bank loan moratorium and free internet facilities. 
Families in need are encouraged to wave a white flag outside their house to signal that they need help. So, whoever spots the white flag can reach out to them (BBC, 2021). If they are uncomfortable to raise the white flag, they can go to the nearest "food banks" to collect free food. Not only are the humanitarians helping, but also many NGOs and private companies are working together to assist the poor.

\section{Get Vaccinated}

Some studies have found that vaccines have been remarkably effective and safe at bringing the COVID-19 under control (Lopez Bernal et al., 2021; Polack et al., 2020). We should get vaccinated as soon as we can. It is a personal responsibility that is doable and beneficial to society. Moreover, we should encourage those who are vaccine-hesitant to get vaccinated. Convince them with facts that countries who have high vaccination rate are already in control of the pandemic, for example like our neighbour country, Singapore. Help people who are not IT savvy to register for a vaccination appointment through their "MySejahtera" app or help to arrange transportation for the needy to the centres. If one more person gets vaccinated, we are one step closer to achieving herd community.

Malaysia has been significantly increasing its vaccination rate, which is aimed on achieving approximately 500,000 vaccinations daily to achieve high-speed goal of immunizing the entire population by October 2021 (Salim, 2021). With the majority of people completely vaccinated, it may reduce the devastating loss of lives. Then, the country's economy and people's well-being will improve. At the time of writing, $20 \%$ of total Malaysia population has already been fully vaccinated, hence to achieve $40 \%$ of full vaccination by year-end target is achievable.

\section{Conclusion}

COVID-19 has affected everyone. MCOs, WFH/LFH and ever-changing SOPs are already a norm. The psychological effects of this pandemic are unavoidable. Therefore, the strategies of internal and external self-care might be a guide to reduce the negative psychology effects. Accept new routines, adapt quickly to new regulations, focus on what we can control, be aware of our emotional changes and always maintain a positive mindset are internal self-care methods which are within our control. Find the right channel for news, get the right resources for help and get vaccinated are the external self-care that we should practice. Beyond the government and the health minister's effort to curb the pandemic, the cooperation of individuals and their initiative are crucial too. With the individual's internal and external selfcare methods, it might improve the well-being of the population and prevent the deterioration of people's mental health issue during and post pandemic.

\section{References}

Analysis: Mental health issues growing more serious. (2021). The Star. https://www.thestar.com.my/news/nation/2021/07/02/analysis-mental-healthissues-growing-more-serious

Banerjee, D. (2020). The COVID-19 outbreak: Crucial role the psychiatrists can play. Asian Journal of Psychiatry, 50, 102014. https://dx.doi.org/10.1016\%2Fj.ajp.2020.102014 
Babulal, V., \& Solhi, F. (2020). Learning institutions floundering. New Straits Time. https://www.nst.com.my/news/nation/2020/06/601611/learning-institutionsfloundering

BBC. (2021). Malaysians in Covid lockdown fly white flags to ask for help. BBC News. https://www.bbc.com/news/world-asia-57717214

Bernama. (2020a). MCO: Impact of digital divide deepens with e-learning. The Star. https://www.thestar.com.my/news/nation/2020/04/17/mco-impact-of-digital-dividedeepens-with-e-learning

Bernama. (2021a). RM10,000 fine for SOP violations beginning March 11. New Straits Times. https://www.nst.com.my/news/nation/2021/02/669100/rm10000-fine-sop-violat ations-beginning-march-11

Bernama. (2020b). It's a national effort to fight fake news during COVID-19, MCO - Saifuddin. Astro Awani. http://english.astroawani.com/malaysia-news/its-national-effort-fightfake-news-during-covid-19-mco-saifuddin-237908

Bernama. (2021b). The National Recovery Plan (Infographics). https://www.bernama .com/en/infographics/index.php?v=7942

Bloomberg. (2021). Malaysia apologises for 'human error' after empty syringe used to deliver coronavirus vaccine. South China Morning Post. https://www.scmp.com/news/asia/ southeast-asia/article/3142225/malaysiaapologises-human-error-after-empty-syringe-used

Blustein, D. L., Duffy, R., Ferreira, J. A., Cohen-Scali, V., Cinamon, R. G., \& Allan, B. A. (2020). Unemployment in the time of COVID-19: A research agenda. Journal of Vocational Behavior, 119.

https://www.sciencedirect.com/science/article/pii/S0001879120300610

Brooks, S. K., Webster, R. K., Smith, L. E., Woodland, L., Wessely, S., Greenberg, N., \& Rubin, G. J. (2020). The psychological impact of quarantine and how to reduce it: Rapid review of evidence. The Lancet, 395(10227), 912-920. https://doi.org/10.1016/S01406736(20)30460-8

Bryce, C., Ring, P., Ashby, S., \& Wardman, J. K. (2020). Resilience in the face of uncertainty: Early lessons from the COVID-19 pandemic. Journal of Risk Research, 23(7-8), 880-887. https://doi.org/10.1080/13669877.2020.1756379

Chan, D. (2020). RM1,000 fine for MCO violators to stay, says Ismail Sabri. New Straits Time. https://www.nst.com.my/news/nation/2020/04/583631/rm1000-fine-mco-violato rs-stay-says-ismail sabri\#: :text=The\%20RM1\%2C000\%20fine\%20will,Infected\%20Local\% 20Areas)\%20Regulations\%202020.

Corona Virus - The situation in Malaysia. (2021). Flanders Trade. Vlaanderen. https://www.flandersinvestmentandtrade.com/export/nieuws/corona-virus\%E2\%80\%93-situation-malaysia

Coyne, L. W., Gould, E. R., Grimaldi, M., Wilson, K. G., Baffuto, G., \& Biglan, A. (2020). First things first: Parent psychological flexibility and self-compassion during COVID19. Behavior Analysis in Practice, 1-7. https://link.springer.com/content/pdf/10.1007/s40617-020-00435-w.pdf

Department of Statistic Malaysia. (2020). Report of Special Survey on Effects of COVID-19 on Economy \& Individual - Round 1. Department of Statistics.

file://C:/Users/LENOVO/Downloads/Report_of_Special_Survey_on_Effects_of_COVID -19_on_Economy_and_Individual-Round-1\%20(1).pdf 
Gangadaran, V. (2021). Covid-19: Malaysians upset by 'double standards' in 3-day rule for ministers. The Star. https://www.thestar.com.my/news/nation/2021/02/09/co vid-19-malaysians-upset-by-039double-standards039-in-3-day-rule-for-ministers

Gangadaran, V. (2021). Jail, RM100,000 fine for those who spread fake news on Covid19. Emergency from Friday. The Star. https://www.thestar.com.my/news/ nation L2021/03/11/jail-rm100000-fine-for-those-who-spread-fake-news-on-covid-19emergency-from-friday-march-12

Goh, J. (2020). Working from home - the new normal. The Edge Malaysia Weekly. https://www.theedgemarkets.com/article/working-home-\%E2\%80\%94-new-normal

Guo, J., Feng, X. L., Wang, X. H., \& van IJzendoorn, M. H. (2020). Coping with COVID-19: Exposure to COVID-19 and Negative Impact on Livelihood Predict Elevated Mental Health Problems in Chinese Adults. International Journal of Environmental Research and Public Health, 17(11), 3857. https://dx.doi.org/10.3390\%2Fijerph17113857

Health Minister: Those who got 'empty' vaccine shots will be called in for proper dose. (2021). The Star.

https://www.thestar.com.my/news/nation/2021/07/20/health-minister-thosewho-got-039empty039-vaccine-shots-will-be-called-in-for-proper-dose

Hoof, E. V. (2020). Lockdown is the world's biggest psychological experiment - and we will pay the price. The World Economic Forum COVID Action Platform. https://www.weforum .org/agenda/2020/04/this-is-the-psychological-side-of-the-covid-19-pandemic-thatwereignor ing/

Karim, K. (2020). 24 charged for spreading fake news on Covid-19. New Straits Time. https://www.nst.com.my/news/crime-courts/2020/04/584923/24-charged-spreadingfake-news-covid-19.

Kelland, K. (2020). U.N. warns of global mental health crisis due to COVID-19 pandemic. The Star. https://www.thestar.com.my/news/world/2020/05/14/un-warns-of-globalmental-health-crisis-due-to-covid-19-pandemic

Lee, P. S., Leung, L., Lo, V., Xiong, C., \& Wu, T. (2011). Internet communication versus face-toface interaction in quality of life. Social Indicators Research, 100(3), 375-389. http://doi.org/10.1007/s11205-010-9618-3

Lee, T. Y. (2020). Malaysian student sits exams in a tree to ensure good Wi-Fi. BBC NEWS. https://www.bbc.com/news/blogs-news-from-elsewhere-53079907

Lopez Bernal, J., Andrews, N., Gower, C., Gallagher, E., Simmons, R., Thelwall, S., . . Ramsay, M. (2021). Effectiveness of Covid-19 Vaccines against the B.1.617.2 (Delta) Variant. New England Journal of Medicine, 385, 585-594. https://doi.org/10.1056/NEJMoa2108891

Lost Job Assistance. (2021). Building Careers and Retirement. https://www.malaysia.gov.my /portal/content/30430

Lyon, B. L. (2002). Cognitive self-care skills: a model for managing stressful lifestyles. The Nursing clinics of North America, 37(2), 285-294. https://doi.org/10.1016/s00296465(01)000 07-x.

Man scavenges for food in rubbish bins. (2021). The Star. https://www.thestar. com.my/news/nation/2021/07/01/man-scavenges-for-food-in-rubbish-bins

Maulik, P. K., Thornicroft, G., \& Saxena, S. (2020). Roadmap to strengthen global mental health systems to tackle the impact of the COVID-19 pandemic. International Journal of Mental Health Systems, 14(1), 1-13. https://doi.org/10.1186/s13033-020-00393-4 
McGaughey, E. (2020). COVID-19 and job security: How to prevent a 'pandemic of unemployment'. The London School of Economic and Political Science. https://blogs.Ise.ac. uk/politicsandpolicy/covid19-job-security/

Ministry of Finance. (2021). Press Citations. https://www.mof.gov.my/en/news/presscitations/govt-launches-pemulih-package-worth-rm150-bln-including-fiscal-injectionof-rm10-bln-pm

Ministry of Health. (2020a). Situasi Terkini 25 Julai 2020. https://covid19.moh.gov.my/terkini/072020/situasi-terkini-25-julai-2020

Ministry of Health. (2021a). Situasi Terkini 12 Januari 2021. https://covid19.moh.gov.my/terkini/2021/01/situasi-terkini-covid-19-di-malaysia-12012021

Ministry of Health. (2021b). Situasi Terkini 25 Julai 2021. https://covid19.moh.gov.my/terkini/2021/07/situasi-terkini-covid-19-di-malaysia-25072021

Ministry of Health. (2020b). Situasi Terkini 18 Mac 2020. https://covid19.moh.gov.my/terkini/032020/situasi-terkini-18-mac-2020

Ministry of Health. (2020c). Situasi Terkini 18 Mei 2020. https://covid19.moh.gov.my/terkini/052020/situasi-terkini-18-mei-2020

Nixon, S. (2021, June 10). Commentary: Resurgent pandemic sparks unemployment crisis among Malaysia's most vulnerable workers. CNA.

https://www.channelnewsasia.com/news/ comme ntary/malaysia-covid-19-economymco-johor-worker-graduate-jobs-skills-14979404

Noh, N. H., \& Nawa, N. D. (2020). Chapter 6 Issues and Challenges. A report on FSSH UTM's experience towards digitizing education. 46-54.

https://humanities.utm.my/wpcontent/uploads /2020/06/V1-A-REPORT-ON-FSSHUTMS-EXPERIENCE-TOWARDS-DIGITIZINGEDU CATION.pdf\#page $=45$

Pfefferbaum, B., \& North, C. S. (2020). Mental health and the Covid-19 pandemic. New England Journal of Medicine, 383(6), 510-512. https://doi.org/10.1056/NEJMp2008017

Polack, F. P., Thomas, S. J., Kitchin, N., Absalon, J., Gurtman, A., Lockhart, S., . . Gruber, W. C. (2020). Safety and Efficacy of the BNT162b2 mRNA Covid-19 Vaccine. New England Journal of Medicine, 383(27), 2603-2615. https://doi.org/10.1056/NEJMoa2034577

Rampal, L., \& Liew, B. S. (2021). Malaysia's third COVID-19 wave-a paradigm shift required. The Medical Journal of Malaysia, 76(1), 1-4. https://pubmed.ncbi.nlm.nih.gov/3351 0100/

Reuters. (2020). Wuhan lockdown 'unprecedented', shows commitment to contain virus: WHO representative in China. https://www.reuters.com/article/us-china-health-whoidUSKBN1ZM1G9

Savitha, A. G. (2020). \#KitaJagaKita: Here's how Malaysians can take care of each other amid movement control order. Malay Mail. https://www.malaymail.com/news/life/2020/ 03/19/malaysian-author-hanna-alkaf-launches-initiative-to-assist-needycommunitie/1848141

Salim, S. (2021). Malaysia set record high of 556,404 daily Covid-19 vaccine doses administered on July 29, 43\% in Klang Valley. The Edge Markets. https://www.theedgemar kets.com/article/malaysia-sets-record-high-556404-dailycovid19-vaccine-doses-administeredjuly -29-43-klang

Schladebeck, J. (2020). Nearly one in five coronavirus patients diagnosed with mental illness, new study says. New York Daily News. https://www.nydailynews.com /coronavirus/nycoronavirus-one-five-survivors-diagnosed-mental-illness-20201110 26x4fms35jdafezwsedm3fffiu-story.html 
Sekowski, M., Gambin, M., Hansen, K., Holas, P., Hyniewska, S., Pluta, A., ... \& Łojek, E. (2021). Risk of developing posttraumatic stress disorder in COVID-19 survivors: What should mental health specialists prepare for?. Frontiers in Psychiatry. https://doi.org/10.3389/fp syt.2021.562899

Shah, A. U. M., Safri, S. N. A., Thevadas, R., Noordin, N. K., Abd Rahman, A., Sekawi, Z., Ideris, A., \& Sultan, M. T. H. (2020). COVID-19 Outbreak in Malaysia: Actions taken by the Malaysian government. International Journal of Infectious Diseases, 97, 108-116. https://dx.d oi.org/10.1016\%2Fj.ijid.2020.05.093

Solhi, F., \& Krishnan, D. B. ( 2021). Contract doctors nationwide go on strike. The Straits Times. https://www.nst.com.my/news/nation/2021/07/711788/contract-doctorsnationwide-go-strike

Sood, S. (2020). Psychological effects of the Coronavirus disease-2019 pandemic. Research \& Humanities in Medical Education, 7(11), 23-

26.https://www.rhime.in/ojs/index.php/rhime/ article /view/264/280

Sundarasen, S., Chinna, K., Kamaludin, K., Nurunnabi, M., Baloch, G. M., Khoshaim, H. B., ... \& Sukayt, A. (2020). Psychological impact of COVID-19 and lockdown among university students in Malaysia: implications and policy recommendations. International Journal of Environmental Research and Public Health, 17(17), 6206. https://doi.org/10.3390/ijerph1717 6206

Sunstein, C. R. (2020). The Cognitive Bias That Makes Us Panic about Coronavirus. Bloomberg Opinion. https://www.bloomberg.com/opinion/articles/2020-02-28/coronaviruspanic-caused-by-probability-neglect

Tang, A. (2020). Health DG: 9,338 calls made to ministry hotline, most requiring emotional support. The Star. https://www.thestar.com.my/news/nation/2020/06/03/health-dg9338-calls-made-to-ministry-hotline-most-requiring-emotional-support

Tee, K. K., Takebe, Y., \& Kamarulzaman, A. (2009). Emerging and re-emerging viruses in Malaysia, 1997-2007. International Journal of Infectious Diseases, 13(3), 307-318. https://doi.org/10.1016/j.ijid.2008.09.005

Teoh, S. (2021). Malaysia's King declares state of emergency till Aug 1 to curb spread of Covid-19. The Straits Times. https://www.straitstimes.com/asia/se-asia/malaysiasking-declares-national-state-of-emergency-to-curb-spread-of-covid-19

The Malaysian Reserve. (2021). MSME sector suffered RM40.7b losses in 2020, 49\% at risk of collapse by Oct 2021. https://themalaysianreserve.com/2021/07/29/msme-sectorsuffered-rm40-7b-losses-in-2020-49-at-risk-of-collapse-by-oct-2021/

The World Bank. (2021). Emerging economic growth trends in Malaysia threatened by resurging pandemic, says latest world bank economic monitor [Press Release]. https://www.worldbank.org/en/news/press-release/2021/06/23/emerging-economicgrowth-trends-in-malaysia-threatened-by-resurging-pandemic-says-latest-world-bankeconomic-monitor

Wang, C., Pan, R., Wan, X., Tan, Y., Xu, L., Ho, C. S., \& Ho, R. C. (2020). Immediate psychological responses and associated factors during the initial stage of the 2019 coronavirus disease (COVID-19) epidemic among the general population in China. International Journal of Environmental Research and Public Health, 17(5), 1729. https://www.mdpi.com/16604601/17/5/1729/htm 
Wong, L. P., Alias, H., Md Fuzi, A. A., Omar, I. S., Mohamad Nor, A., Tan, M. P., ... \& Chung, I. (2021). Escalating progression of mental health disorders during the COVID-19 pandemic: Evidence from a nationwide survey. PloS One, 16(3), e0248916. https://doi.org/10.1371/journ al.pone.0248916

World Health Organization. (2020a). Novel Coronavirus(2019-nCoV) Situation Report - 11. https://www.who.int/docs/default-source/coronaviruse/situation-reports/20200131sitrep-11-ncov.pdf?sfursn=de7c0f7_4

World Health Organization. (2020b). Coronavirus disease (COVID-19): Herd immunity, lockdowns and COVID-19. https://www.who.int/news-room/q-a-detail/herdimmunity-lockdo wns-and-covid-19.

Yeoh, A. (2020). MCO: As lessons move online, local teachers and students struggle with uneven Internet access. The Star. https://www.thestar.com.my/tech/tech-news/2020 /04/27/mco-as-lessons-move-online-local-teachers-and-students-struggle-withuneven-interne et-access

Yusof, A. N. M., Muuti, M. Z., Ariffin, L. A., \& Tan, M. K. M. (2020). Sharing Information on COVID-19: the ethical challenges in the Malaysian setting. Asian Bioethics Review, 12(3), 349-361. https://dx.doi.org/10.1007\%2Fs41649-020-00132-4

Table 1: Comparison of July 2020 and July 2021 Confirmed COVID-19 Cases in Malaysia

Date:25/7/2020

New Cases: 123

Total Cases:8,884
Date:25/7/2021

New Cases: 17,045

Total Cases:1,013,438

Source: Ministry of Health, Malaysia (https://www.moh.gov.myL

Table 2: The Phases of MCOs in Malaysia

\begin{tabular}{|c|c|c|c|c|}
\hline Phase & Duration & Duration & Term & Actions Taken by Government \\
\hline 1 & $\begin{array}{l}18.03 .2020- \\
31.03 .2020\end{array}$ & 2 weeks & $\begin{array}{l}\text { MCO \& } \\
\text { EMCO* }\end{array}$ & $\begin{array}{l}\text { Closure of all pre-schools, } \\
\text { government and private } \\
\text { schools, all houses of } \\
\text { worship and business } \\
\text { premises, with the } \\
\text { exception of } \\
\text { supermarkets, public } \\
\text { markets, and sundry } \\
\text { and convenience shops } \\
\text { which sell daily } \\
\text { essentials. }\end{array}$ \\
\hline
\end{tabular}

\begin{tabular}{ccccc}
\hline 2 & $01.04 .2020-$ & 2 weeks & MCO\& EMCO & Similar as above \\
& 14.04 .2020 & & & \\
\hline 3 & $15.04 .2020-$ & 2 weeks & MCO\& EMCO & Similar as above \\
& 28.04 .2020 & & & \\
\hline 4 & $29.04 .2020-$ & 2 weeks & MCO & University students were \\
12.05 .2020 & & & $\begin{array}{l}\text { given green light to go } \\
\text { home and those who }\end{array}$ \\
& & & & \\
\hline
\end{tabular}




\begin{tabular}{|c|c|c|c|c|}
\hline & & & & $\begin{array}{l}\text { were stranded in their } \\
\text { hometowns were } \\
\text { allowed to travel back. }\end{array}$ \\
\hline 5 & $\begin{array}{r}13.05 .2020- \\
09.06 .2020\end{array}$ & 4 weeks & CMCO* & $\begin{array}{l}\text { Many industries and } \\
\text { businesses were } \\
\text { allowed to start } \\
\text { operating. Police, } \\
\text { Malaysian Armed } \\
\text { Forces and other } \\
\text { enforcement officers to } \\
\text { move their focus to } \\
\text { enforcing compliance of } \\
\text { Standard Operating } \\
\text { Procedures (SOPs) and } \\
\text { the application of social } \\
\text { distancing. }\end{array}$ \\
\hline 6 & $\begin{array}{r}10.06 .2020- \\
31.12 .2020\end{array}$ & 6 months & RMCO* & $\begin{array}{l}\text { Most business, economic, } \\
\text { social, educational and } \\
\text { religious sectors are } \\
\text { allowed to resume their } \\
\text { operations by stages } \\
\text { with stringent SOPs and } \\
\text { the application of social } \\
\text { distancing. }\end{array}$ \\
\hline
\end{tabular}

\section{1}

MCO by states (11 Jan 2021 -31 May 2021)

Each state switch between MCOs, CMCO, RMCO, EMCO depends on the COVID-19 condition in each state.

\begin{tabular}{|c|c|c|c|c|}
\hline 7 & $\begin{array}{r}01.06 .2021- \\
28.06 .2021\end{array}$ & 1 month & FMCO & $\begin{array}{l}\text { All sectors are not allowed to } \\
\text { operate, with the } \\
\text { exception of essential } \\
\text { economic and service } \\
\text { sectors }\end{array}$ \\
\hline 8 & $\begin{array}{l}29.06 .2021 \\
\text { Extended }\end{array}$ & $\begin{array}{r}\text { No specific } \\
\text { date }\end{array}$ & $\begin{array}{l}\text { MCOs } \\
\text { (Depends on } \\
\text { condition } \\
\text { in each } \\
\text { state) }\end{array}$ & $\begin{array}{l}\text { No specific date given but } \\
\text { until three threshold } \\
\text { indicators below } \\
\text { fulfilled: Less than } 4000 \\
\text { daily infection cases, } \\
\text { ICU wards start } \\
\text { operating at a } \\
\text { moderate level and } \\
\text { nation vaccination rate }\end{array}$ \\
\hline
\end{tabular}


reaches $10 \%$ of the population.

\section{Notes:}

EMCO*: Enhanced MCO (Quarantine in specific areas for 14 days if a cluster was detected) CMCO*: Conditional MCO (More relaxed enforcement, more activities are allowed)

RMCO*: Recovery MCO (Majority of the sectors to resume operations in stages)

FMCO*: Full MCO/Total lockdown (all economic sectors are not allowed to operate except essential sectors)

Table 3: Confirmed Cases from the Day of Emergency Order

\begin{tabular}{ll}
\hline Date:12/1/2021 & Date:25/7/2021 \\
New Cases: 3,309 & New Cases: 17,045 \\
Total Cases: 141,533 & Total Cases:1,013,438
\end{tabular}

Source: Ministry of Health, Malaysia (https://www.moh.gov.myL

Figure 1: Internal and External Self-Care

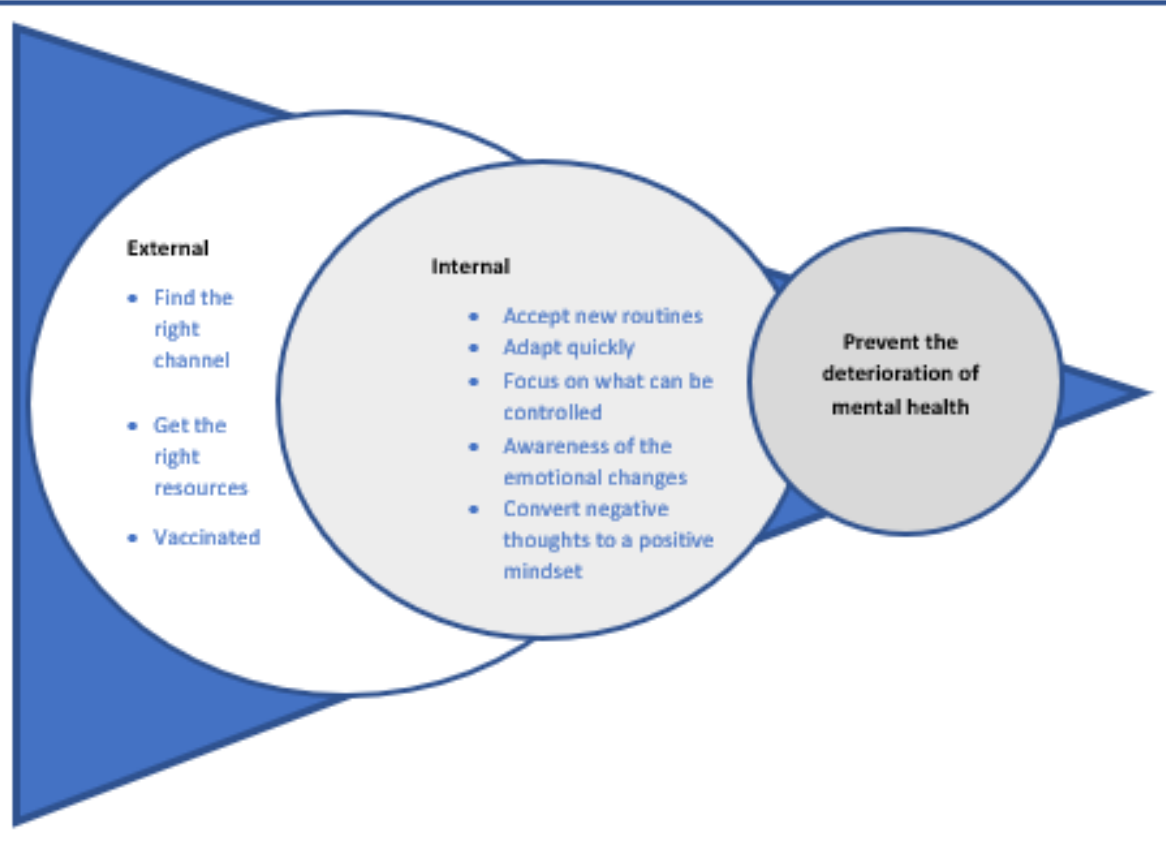

